\title{
Cultural and legal significance of the Supreme Court of the United States
}

\author{
Elena Aleksandrovna Ageeva ${ }^{1}$, Svetlana Vladimirovna Maksina $^{1}$ and Sulaymon Zarobidin \\ Muzafarov $^{2}$ \\ ${ }^{1}$ Saint Petersburg State University of Economics, Saint Petersburg, Russia \\ ${ }^{2}$ Academy of the Ministry of Internal Affairs of the Republic of Tajikistan, Faculty No. 2, Department \\ of state legal disciplines, Tajikistan
}

\begin{abstract}
The study's objective is to reflect on the cultural and legal experience of the United States Supreme Court as the oldest body of constitutional justice, with its long legal tradition, which seems essential for states undergoing constitutional law reform. The study used general scientific methods of analogy, classification, typology, systematization, analysis, and others, as well as special scientific methods such as systematic, functional, historical, the study of judicial practice (which included observation and description), the method of comparative law, etc., which allowed to present the views of the authors, and thus to achieve the objective of the study. The results and novelty of the work are to identify the cultural and legal significance of the activities of the highest judicial instance of the United States in the formation of the legal culture of American society. The authors address the genesis of the cultural and legal aspects of the U.S. Supreme Court, which served as the basis for the formation and implementation of constitutional rights and freedoms in the American state.
\end{abstract}

Keywords: Anglo-Saxon legal family, legal culture, U.S. legal system, U.S. Supreme Court, U.S. Supreme Court decisions

\section{Introduction}

At present, legal culture and legal consciousness issues are more relevant than ever in the changing under the influence of various circumstances, state, and legal life. The theory of state and law has for a long time been faced with the question of what is legal culture, what is included in its structure, and what is its functional role.

The level of democracy in the modern state is proportional to the legal culture of society, which is characterized by the level of democratic institutions, legal consciousness, implementation of the rights and freedoms of citizens, depends on several economic, political, social factors and spiritual-cultural sphere of society, which undoubtedly entails the relevance of the study of factors of legal culture formation, its elements, especially when it comes to the experience of the oldest judicial body in the world.

\footnotetext{
${ }^{1}$ Corresponding author: elenaageeva2013@mail.ru
} 
Legal culture is a part of the general culture of a person and society. Speaking in general about the Anglo-Saxon legal family, we agree that it acts as "a unique cultural and legal phenomenon" [1]. The legal culture of the United States, among other things, is the result of the historically established legal practice of this state and, above all, its superior court - the Supreme Court, in the activities of which the legal culture deserves a separate study, having acquired a specific content.

\section{Methods}

Using an axiological approach, it should be noted that the authors reveal the cultural and legal significance of the U.S. Supreme Court through the most significant areas of its functioning, beginning with the formation of the Court, the requirements for judges, their dissenting opinions, and certain categories of disputes involving human rights, which are of the highest value. For the judges themselves, legal culture is a form of awareness of the needs of public life that require regulation, and the decisions of the highest court in the United States help to consolidate the legal foundations of power, define the boundaries of freedom, and ensure a universal, stable rule of law [2].

\section{$3 \quad$ Results and discussion}

The origins of America's legal culture are in colonial times, being directly linked to the names of the founding fathers of American constitutionalism [2], we cannot but mention James Madison, Thomas Jefferson, John Adams, Benjamin Franklin, John Jay, Alexander Hamilton, and George Washington, who contributed significantly to the establishment of democratic institutions. They sought to create a government that did not function by overcoming human weaknesses but rather used those very human weaknesses to create political stability and maximize individual freedom [3]. The ideas that were once proclaimed and implemented by American thinkers remain relevant for modern political and legal systems of democratic states [4]. In comparison with Russia, the legal system of Western society, based on the legal culture, accompanies a person in all his actions, being a barometer of public life [5].

It may take years, decades, sometimes even a generational change, before minority opinions become the norm of law. The occurrence of such events does not necessarily depend on the degree of persuasiveness of the individual opinion - it depends on a variety of factors: unexpected court vacancies, changes in political forces, sociopolitical changes, etc. Nevertheless, in a vast number of cases in U.S. history, the first signs of impending change, whether in civil rights, regulation of the economy, privacy rights, can be found in the U.S. Supreme Court decision or dissenting opinion.

The decision of any court, especially when it comes to higher courts, requires respect and compliance, but this topic cannot be closed. Issues of interpersonal relations, religious issues, and the protection of human rights require a sensitive approach, and it seems that mandatory norms cannot regulate them.

The history of the highest court shows different stages in its activity, during which "fateful decisions" were made, and the Court earned "no small credibility" [6], acting as a central authority for fundamental structural changes [7], compositions of the Court ranging from ideologically homogeneous to heterogeneous and at times highly polarized, which did not always positively affect the Court, and political-ideological beliefs, predilections, values of judges played an essential role in determining the content and political implication of judicial activity [8]. The difference was also evident in the professional experience of 
judges who had a different experience in lower courts at the federal or state level, as well as politicians, teachers, etc. As practice shows, long experience in the court did not always mean the development of balanced decisions in the position of the supreme judge. An important role is played by the Chairman of the Court, his professional, leadership, and organizational qualities.

New judges are rarely appointed to the Court due to a lack of vacancies, and they may not arise during the President's four years in office. J. Washington, which established the first composition of the Court, nominated ten people, F. D. Roosevelt, who served as head of state four times - nine, D. Trump - three. Congress has not used the constitutional right to change the number of judges since 1869: at the very beginning, there were 6 judges, as the territorial changes of the state, in $1807-7$, in $1837-9$, in $1863-10$, in $1866-9$, in $1867-8$, since $1869-9$.

For a long time before 1835, the Court's composition was quite conservative: the judges of the highest court were only men, usually of the Protestant faith. The first Catholic on the Court was Roger Brooke Taney, whose name is mentioned in connection with the Dred Scott decision (1857), which caused more controversy in national politics and dangerously undermined the prestige of the Supreme Court. Later - in 1916 - a Jewish judge, L. Brandeis, joined the Court, and in 1967 an African American, Thurgood Marshall, was appointed to the Court, an exception to the modest expectations of black Americans in the early twentieth century [9]. Before that, throughout the 1940s and '50s, Marshall had established himself as one of the nation's top lawyers, winning 29 of the 32 cases before the Supreme Court. These included cases in which the Court declared the Southern state's exclusion of African-American voters from primary elections unconstitutional (Smith v. Allwright (1944)), judicial enforcement of racial "restrictive covenants" in housing (Shelley v. Kraemer (1948)), and "separate but equal" conditions for African American professionals and graduate students at public universities (Sweatt v. Painteri McLaurin v. Oklahoma State Regents, both 1950). In 1991, summing up his career, Marshall said, "He did what he could with what he had" [10].

Moral tenets are organically woven into questions of judicial formation, judicial decisions, and the dissenting opinions of judges. "The right to a different opinion is the essence of democracy," said J. Carter, associate justice of the California Supreme Court from September 12, 1939 - March 15, 1950 [11]. The institution of dissenting opinion originated in the U.K. and is now widespread in foreign countries. The United States is no exception.

A specific role is played by the institution of special opinion, concerning which there are different approaches in foreign countries. In the United States, the institution of dissenting opinion is an attribute of the judicial process. A famous example of the validity of a dissenting opinion is the dissenting opinion in Plessy v. Ferguson 1896, which confirmed the legality of racial segregation by establishing the doctrine of "separate but equal". In a dissenting opinion, Judge Harlan sharply expressed his view on discrimination: "This cannot be justified on any legal grounds" [12]. More than half a century was required to confirm the correctness of his words, in 1954 (Brown v. Board of Education), when the Court changed its position.

Speaking about the legal culture of the United States, it should be noted about its deeply religious and historical roots. Religion, being the basis of spiritual culture, traditionally plays a central role in the political culture of the United States [13], and the issues of cultural and religious diversity are of particular importance, which necessitates addressing them and a certain rethinking in light of contemporary realities. 
The United States belongs to the group of countries with a pronounced diversity of religious denominations, and the public policy of the American state is characterized, while maintaining the influence of the church in the social sphere, including education, the system of which "is part and product of the culture of any society" [14]. Religious issues are impacted not only by constitutional standards but also by court decisions. All of the cases of this field that have come to the attention of the U.S. Supreme Court can be divided into a number of areas: cases on prayer in school, public funding of religious organizations, freedom of expression, other human rights issues. By the early 1950s, the problems of attitudes toward religion in schools were coming to the fore, and the Supreme Court could not stand by in issuing verdicts prohibiting religious expression in public schools, a situation in which U.S. authorities had to preserve religion as a measure of moral influence on students.

\section{Conclusion}

The United States has a unique model of state and legal development. The state has passed a complex constitutional and legal way of regulating various spheres of social relations, protection of human rights, where the activity of the Supreme Court, as the highest judicial instance, strengthens the democratic mechanisms of protection of rights and freedoms by its decisions, is of great importance.

The activity of the Supreme Court, the decisions made, the dissenting opinions of judges, the legal consciousness of judges - are elements of the legal culture, at the same time acting as indicators of the development of the legal culture of society as a whole. For judges, a legal culture is a form of awareness of the needs of public life that require regulation and resolution. Further scientific research should contribute to the study to build the optimal model of relations between the state and society, no matter the field they are carried out.

\section{References}

1. E.V. Bychkova, Pravovaya kultura v anglosaksonskoi pravovoi seme (teoretiko-pravovoe issledovanie) [Legal culture in the Anglo-Saxon legal family (theoretical and legal research)], Abstract of a PhD thesis, 6 (Volgograd, 2003)

2. S.L. Sergeeva, Historical and Legal Problems: a New Perspective, 5, 243-258 (2012)

3. R.M. Allalyev, Economy. Law. Society, 3, 25 (2018)

4. V.A. Ignatenko, Faktory, povliyavshie na pravovuyu kulturu amerikanskogo obshchestva na etape obrazovaniya SShA [Factors that influenced the legal culture of American society at the formation of the United States], in Socio-Humanitarian Bulletin. All-Russian collection of scientific papers, 105-114 (Krasnodar, 2019)

5. M.G. Shulman, N.A. Shcherbakova, Bulletin of the Educational Consortium. Central Russian University, 10, 101-104 (2017)

6. E.A. Ageeva, Legal Science: History and Modernity, 12, 168-171 (2018)

7. L. Guinier, Boston University Law Review, 89, 554 (2009)

8. J.M. Burman, Wyoming Law Review, 13(1), 189-214 (2013)

9. E.A. Ageeva, News of Higher Educational Institutions, 2(46), 60-66 (2018)

10. J. Williams, Thurgood Marshall: American Revolutionary (Three Rivers Press, New York, 1998) 
11. J.W. Carter, Hastings Law Journal, 4(1), 118-123, 118 (1953)

12. G. McKenna (ed.), A guide to the Constitution that delicate balance, 384-386 (New York, 1984)

13. O.A. Frolova, Bulletin of the PFUR. Political Science Series, 4, 66-67 (2016)

14. M.P. Loginova, Bulletin of the Saint Tikhon's Orthodox University, 54, 9 (2019) 